\title{
女子学生の塩味に対する味覚特性と食物摂取状況
}

\author{
田中順子* · 田原モ卜子** · 山本由喜子*** \\ $(*$ 大阪信愛女学院短期大学 $\cdot * *$ 平安女学院短期大学 $\cdot * * *$ 大阪市立大学 $)$
}

\section{Studies on the eating habits of famale students and the properties of their salt-taste perception}

\author{
Yoriko Tanaka*, Motoko Tahara**, Yukiko Yamamoto***
}

*Department of Human Life Science, Osaka Shin-Ai College, 2-7-30

Furuichi, Joto-ku, Osaka, 536-8585 Japan

**Department of Human Life Science, Heian Jogakuin (St. Agnes') College, 5-81-1 Nampeidai, Takatsuki, Osaka, 569-1092 Japan

***Faculty of Human Life Science, Osaka City University, 3-3-138 Sugimoto, Sumiyoshi-ku, Osaka, 558-8585 Japan

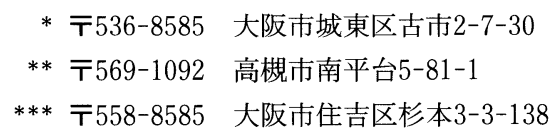

The correlation between the eating habits of female students and the properties of their perception for salt-taste, sensitivity and preference were studied. The sensitivity was estimated by measuring the detection threshold using thirteen concentrations of salt in water, and the preference was assessed using a five hedonic rating scale with misoshiru (misosoup). Their eating habits were studied with a questionnaire.

A high sensitivity to the taste of salt and a high preference for a low salt taste were found in the subjects who answered the salt intensity level in their home dishes as being relatively low. Students who had the habit of using less salt preferred the less salty misoshiru, and their mothers also answered as wishing to ues less salt. Students whose mothers wanted to use less salt answered the salt intensity level in their home dishes as being relatively low. These results suggested that the sensitivity and preference for salt - taste in female students were related to their eating habits. This study also showed that female students eating fewer vegetables, soy beans and soy bean products more frequently used ready - made lunch boxes, instant foods, and snack foods, suggesting a tendency to ingest much more salt.

\section{1. 緒言}

近年の我が国では食料の供給は豊かになったが，食生 活の多様化, 簡略化, 個食化傾向が強まり，それにとも
なう弊害が䯚念されるようになってきた，朝食の欠食の 増加, 外食や調理済久食品の普及, 夕食時間が遅くなり 不規則になる傾向など, 食生活上の問題点が指摘されて いる1). 
このような食生活上の变化は，味覚や食品に対する墸 好性に影響を与えることが予想される。味覚や嗜好性と 食生活状況の関連については, 生育時における食事や親 の喈好性の影響に関する報告がみられるが，それらの間 に明らかな関連性は認められていない2，3)。

各種の味覚の中で塩味については, 味覚や嗜好性の形 成への食塩摂取状況の影響が，とりわけ広範に研究され てきた。その結果，食塩の摄取量が多い場合に塩味に対 する嗜好性が上昇し，摂取量が少ない場合に嗜好性が低 下することが示されたが4 8), 一方, 高食塩食では塩味 に対する嗜好性が低下することも認められている ${ }^{9,10)}$. これらの相反する結果とは別に, 食塩摂取量の多少が塩 味に対する味覚や嗜好性に影響しなかったという結果も 報告されている11)。このように，塩味に対する味覚や 嗜好性への生育時における食塩摂取状況の影響について は，いまだ一致した結論を得ていない。

4 基本味の一つである塩味は最も重要な味覚の一つで あり，食物の扔いしさに対する影響は大きい。しかし， 食塩の過剰摂取は, 高血圧, 脳卒中, 循環器疾患等の発 症との関連性が指摘され, 健康上問題である. 現在, 日 本人の食塩摂取量は 1 人, 1 日当たり $12.9 \mathrm{~g}$ で1)，厚生 省の目標摂取量の $10 \mathrm{~g}$ をかなり上回り, 疾病予防の観点 から食塩の摂取量を減少させることが望をれている。こ のような健康管理の観点からも, 食塩に対する味覚と啫 好性の形成を明らかにすることは重要な課題である.

本研究では, 女子学生と家庭における調理担当者を対 象に, 食物摂取状況と, 塩味に対する感度や嗜好性など の味覚特性を調べ，それらの関連性を检討した。なお本 報告では, アンケート調査結果のうち女子学生による回 答を中心に検討した.

\section{2. 方 法}

\section{1. 食物摂取状況調査}

大阪府内の生活学系の大学・短期大学に在籍する18〜 22歳の女子学生, およびその家庭に打ける調理担当者

（本人を除く）を対象に，食習慣に関するアンケート調 查を実施した。女子学生 254 名より回答を得, 回収率は 92.1\%であった。 また, 調理担当者は 199 名より回答を 得, 回収率は $78.3 \%$ であった. 実施時期は1999年 7 月, 方法は質問紙法によった.

調査内容は, 減塩意識や家庭料理の味付け, 調味料の 使い方, 朝食 - 夕食内容, 料理の好及等の一般的な質問 項目と，18食品の摂取頻度および喍好度である．摂取頻 度は「毎日食べる」「 2 日に 1 回」「 3 日に 1 回」「 1 週
間に 1 回」「ほとんど食べない」の 5 段階とし, 便宜的 にそれぞれ 5 点, 4 点, 3 点, 2 点, 1 点として平均得 点を算出した。 また，嗜好度は「好き」「やや好き」「子 つう」「やや嫌い」「嫌い」の 5 段階とし, 同様にそれぞ れ 5 点, 4 点, 3 点, 2 点, 1 点として平均得点を算出 した.

女子学生本人については, 各大学毎に一斉に自己記入 させてその場で回収した. 調理担当者用の調査用紙は自 宅に持ち帰らせ, 調理担当者本人に記入してもらったも のを回収した. 調理担当者の内訳は母親186人 (93.5\%), その他 13 人 (6.5\%) で, 大多数が母親であったので以 後母親と称する.

\section{2. 官能検査}

\section{(1) 塩味認知閾値の測定}

上記女子学生のうち109名をランダムに選んで対象と し，13段階の濃度の食塩水溶液を用いて全口腔法の上昇 系列で塩味認知閾値を測定した。食塩水溶液は, $2.0 \mathrm{mmol} / 1(0.0117 \%)$ 加 $24.0 \mathrm{mmol} / 1(0.1404 \%)$ まで $2.0 \mathrm{mmol} / 1$ 間隔で調製した。各濃度の食塩水溶液 $5 \mathrm{ml}$ を小カップに入れて供し, 最初に水で口をすすが せた後, 薄い方から順次, カップの液を全量口に含んで 口全体で味わって飲み込ませ, 初めて塩味を感じたカッ プの記号を記入させた. 検査時の室温は $21^{\circ} \mathrm{C}$ に調整し， 食事の影響を受けないような時間帯（午前10時〜11時） に検査を実施した。

\section{（2）味噌汁の塩味嗜好試験}

塩味認知閾值を測定した同じ被験者につき，味噌汁の 塩味に関する嗜好試験を実施した。市販だし入り味増

（マルコメ特選：食塩 $12.0 \%$ 含有）を沸騰水でといて食 塩濃度 $0.8 \%$ の味増汁を調製し, 発砲スチロールのカッ プに約 $100 \mathrm{ml}$ 入れて被験者に供した. 最初に水で口をす すがせてから味噌汁を飲をせ, 塩味の濃さの好みについ て「濃い」「やや濃い」「丁度よい」「やや薄い」「薄い」 の 5 段階で評価させた. 検査時の味噌汁の温度は約 $60^{\circ} \mathrm{C}$ とし，食事の影響を受けないような時間帯（午前10時〜 11時）に検査を実施した. 官能検査結果の解析は, 生理 期間中のものを除き，85名について行った.

\section{3 . 統計処理}

データの解析には, 米国 SPSS 社の統計ソフト SPSS （ver. 7.5）を用いた．項目間の関連性を調べるため, 各カテゴリーにつきクロス集計表を作成し， $\chi^{2}$ 検定によ る分析を行った。また，グループ間の差をみるため Wilcoxonn や Kruskal-Wallis の順位和検定を行った. さらに, 食品摂取頻度調査の結果について各食品間の関 
日本食生活学会誌

連性を調べるため, Spearmanの順位相関係数を求め, 相関分析を行った.

\section{3. 結果}

\section{1．学生の塩味に対する認知閾值と嗜好性}

学生の塩味認知閾值は $2.0 \mathrm{mmol} / 1 \sim 24.0 \mathrm{mmol} / 1$ の 広い範囲に分布した（図 1 ）。最頻值は $6.0 \mathrm{mmol} / 1$ (0.035\%) であり, 平均值は $10.7 \mathrm{mmol} / 1(0.062 \%)$ であった．同年代の女性の塩味閾值については，0.02〜 $0.03 \%$ (全口腔法) ${ }^{3)} ， 0.04 \%$ (万紙法) ${ }^{12)} ， 0.08 \%$ (全口腔法) ${ }^{2,13)}, 0.0256 \mathrm{M}$ (全口腔法) 14) 等にピー クがあるとする報告があり, 研究者により, また検查法 の細部の差により開きがみられる. 我々の今回の最頻値 は, 岡本ら ${ }^{3)}$ の18〜20歳の女子学生の結果と近似してい るが, 他の研究結果と比べてやや低い值であり, 平均值 も岡本ら ${ }^{13)}$ による20歳女子の値（約 $0.09 \%$ ）や石田 ${ }^{15)}$ による女子大学生の値 $(19.8 \mathrm{mmol} / \mathrm{l})$ より低かった。

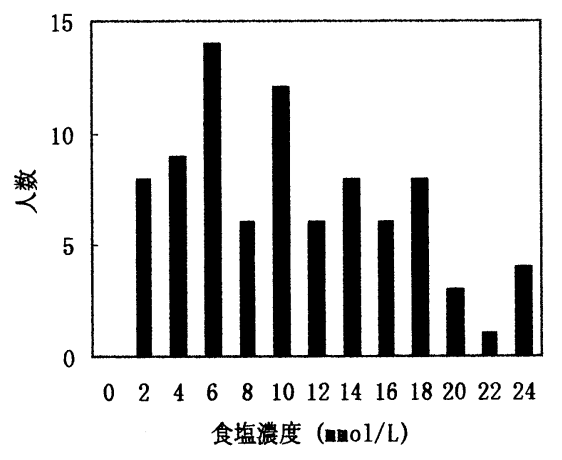

図 1 塩味認知閾値

次に, 塩味に対する嗜好性をみるため, 食塩濃度 0.8 \%の味噌汁の好みを調べた。この塩分濃度の味噌汁に対 して, 44.7\%の学生が「丁度よい」と答えた. しかし, 9.4\%が「濃い」, 23.5\%が「やや濃い」, $22.5 \%$ が「や や薄い」と判断した（図 2 ).これらの塩味に対する嗜 好性と塩味認知閾値との相関を調べたが，両者に有意な 相関は認められなかった。

\section{2. 減塩意識ならびに家庭の味についての意識と官能検} 査結果の関係

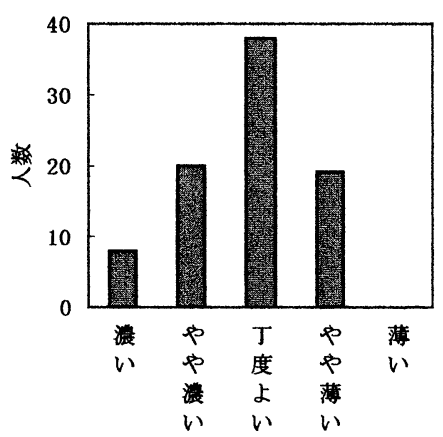

図 2 味噌汁の塩味に関する嗜好性

学生とその母親の味覚に対する意識を, 減塩意識なら びに家庭の味についての意識から調べたが，その結果は 表 1 のようであった. まず家庭の味に対する意識をみた。 家庭の料理の味が一般と比べて「濃い方」「やや濃い方」 と意識している人は，女子学生では， $27.5 \%$ ，母親では $20.6 \%$ であった．また「薄い方」「やや薄い方」と意識

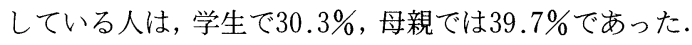
母親の方が「薄い方」と意識している人が多く, 両者に 危険率 $5 \%$ 以下で有意な差が認められた.

一方, 減塩に対する意識は, 両者に明らかな相違が認 められた，母親は減塩を「心がけている」「おおいに心 がけている」と答えた人が $75.9 \%$ あったた.しかし, 学 生ではそれらは20.9\%であり，両者に危険率 $1 \%$ 以下で 有意差があった。

次に, 塩味認知閾值の分布から学生を 3 つの群（2 $6,8 \sim 14,16 \sim 24 \mathrm{mmol} / 1$ l) に分類し, 家庭の味に対 する意識との関連をみた（図 3 ）。その結果, 塩味認知 閾値の低い学生すなわち塩味味覚感度の鋭い人は, 家庭 の味を「薄い方」「やや薄い方」と答えた人が多かった。 また, 塩味認知閾值の高い学生すなわち塩味味覚感度の 鈍い学生は「どちらともいえない」と答えた人が多く, 有意な関連が認められた $(\mathrm{p}<0.05)$.これらの結果か ら, 家庭料理の味付けが学生の塩味認知閾値に影響を与 える可能性が示唆された.

一方, 学生の減塩意識と塩味認知閾值のあいだには有 意な関連は認められなかった。

表 1 女子学生とその母親における家庭の味と減塩に対する意識

\begin{tabular}{|c|c|c|c|c|c|c|c|c|c|c|c|}
\hline \multicolumn{7}{|c|}{ 家庭の味 } & \multicolumn{5}{|c|}{ 減塩意識 } \\
\hline & 濃い方 & やや濃い方 & どちらとむいえない & やや薄い方 & 薄い方 & 検定 & 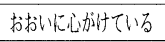 & 心が汁ている & どちらですい & あまり心が忛ていない & 検定 \\
\hline 女子学生 & $9(3.5)$ & $61(24.0)$ & $107(42.1)$ & $62(24.4)$ & $15(5.9)$ & $*$ & $5(2.0)$ & $48(18.9)$ & $113(44.5)$ & $88(34.6)$ & $* *$ \\
\hline 母親 & $6(3.0)$ & $35(17.6)$ & $79(39.7)$ & $64(32.2)$ & $15(7.5)$ & & $20(10.1)$ & $131(65.8)$ & $30(15.1)$ & $18(9.0)$ & \\
\hline
\end{tabular}




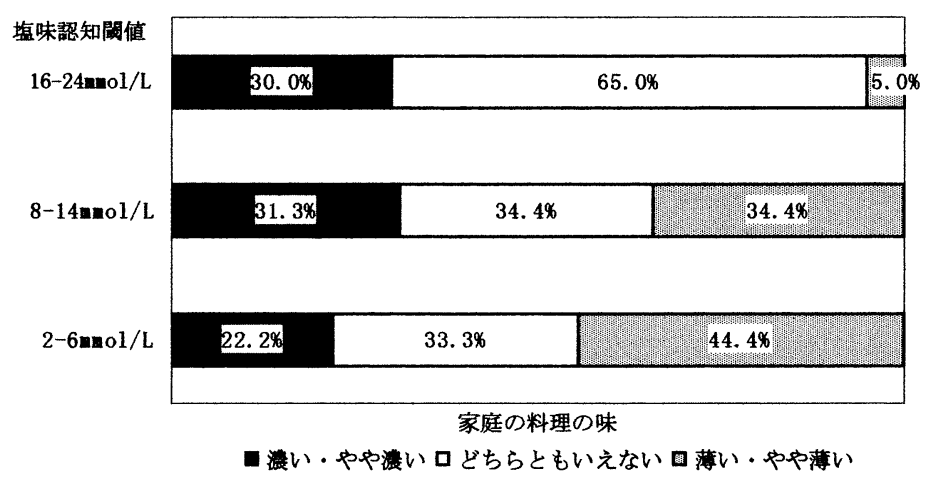

図 3 塩味認知閾値亡家庭の料理の味に対する意識（p<0.05）

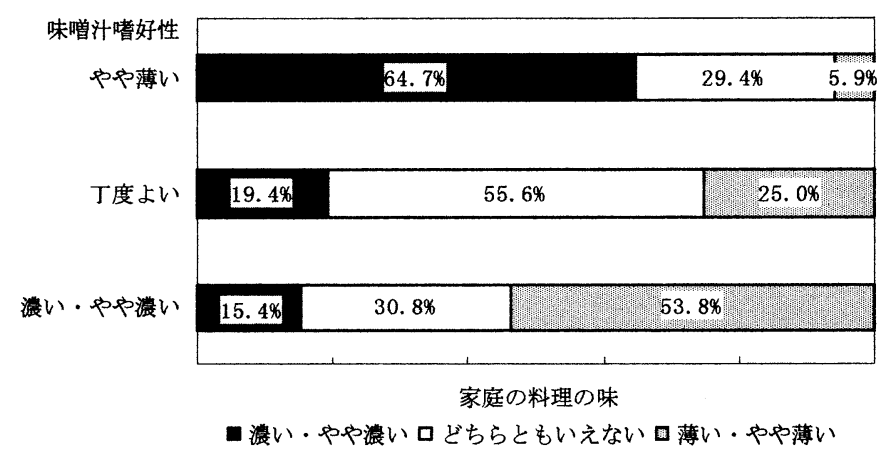

図 4 味噌汁の塩味に対する嗜好性と家庭の料理の味に対する意識（p<0.01）

次に，味噌汁の官能検査結果から，実際の塩味に対す る嗜好性と家庭の味や減塩意識との関連を調べた。 0.8 \%塩分味増汁の塩味が「濃い」「や濃い」と判断した 学生, すなわち薄味嗜好とみなされる（以下「薄味嗜好」 とする）人は家庭の味を「薄い方」「やや薄い方」と答 えた人が多かった（図 4 ). また， $0.8 \%$ 塩分味噌汁の塩 味が「やや薄い」と判断した学生, すなわち濃い味嗜好 とみなされる（以下「濃い味嗜好」とする）人は, 家庭 の料理の味も「濃い方」「やや濃い方」と答えた人が多 かった，味噌汁の塩味に対する嗜好性と家庭料理の味に 対する意識には危険率 $1 \%$ 以下で有意な関連が認められ た。ささらに, 減塩意識との関連をみると,「薄味嗜好」 の人は減塩を心がけている人が多く,「濃い味嗜好」の 人は「心がけていない」人が多かった（ $\mathrm{p}<0.05 ）$ (図 5 ). すなわち, 家庭が薄味傾向である場合や減塩意識 が高い学生は, 比較的薄い塩味を嗜好することが認めら れた。

次に，減塩ならびに家庭の味に対する意識について， 学生と母親との関連をみた。母親の減塩意識が高いほう が低いよりも, 減塩を心がけている学生が多く（図 6 ),
また家庭の味を薄い方と答えた学生が多かった（図 7 ).

これらの結果は, 学生の味覚や減塩意識が, 家庭の味 や母親の意識のような環境要因により影響を受ける可能 性を示唆している.

\section{3. 学生の食品摂取状況之嗜好性}

学生の日常の食生活状況をみるために, 塩分を多く含 む食品や簡便食品などを含む各種食品の摂取頻度と嗜好 性を調べた（表 2 ）.

味噌汁についてみると，「好き」と答えた人が $54.2 \%$ と過半数であり, 平均得点も 4.18 と嗜好度が高い. しか し, 摂取頻度をみると「 1 週間に 1 回」が $32.7 \%$, 次い で「 3 日に 1 回」が $25.1 \%$ であり,「毎日食べる」は $14.7 \%$ と非常に低い.すまし汁・スープも「1 週間に 1 回」が53.8\%であった.

湎類の嗜好度は高かったが，摄取頻度は「1 週間に 1 回」の人が過半数であった. また, 漬け物, 塩干物, 佃 煮・梅干しなどの塩分を多く含む食品の嗜好度は低い傾 向にあり，摂取頻度も低かった．漬け物は「ほとんど食 ベない」 $27.5 \%, 「 1$ 週間に 1 回」 $26.7 \%$ であり, 学生 における摂取頻度は低い。塩干物は「1 週間に 1 回」が 


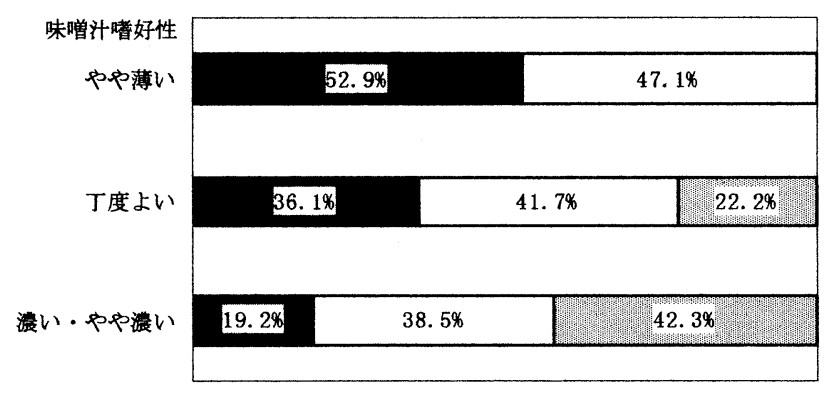

減塩意識

ロ心がけていないロどちらでもないロ大いに心がけている・心がけている

図 5 味噌汁の塩味に対する嗜好性と減塩意識（ $p<0.05 ）$

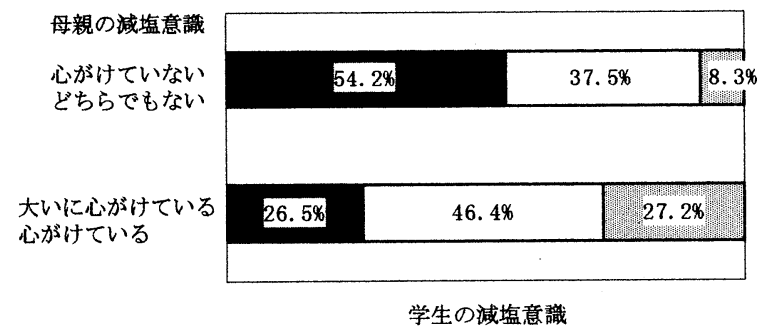

ロ 心がけていないロどちらでもない田大に心がけている・心がけている

図 6 母親の減塩意識と学生の減塩意識 $(p<0.01)$

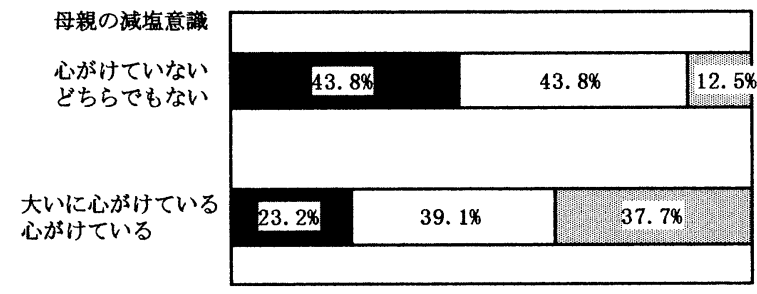

家庭の料理の味に対する学生の意藏

ロ瀑い.やや濃いロどちらともいえない回薄い.やや薄い

図 7 母親の減塩意識と家庭の料理の味に対する学生の意識 $(p<0.01)$

48.8\%であり，「ほとんど食べない」は $31.2 \%$ なっむた。 佃煮・梅干しなども「 1 週間に 1 回」「ほとんど食べな い」が多かった.これらの結果から, 現代の若年世代に おいては伝統的な高塩分食品はあまり好まれず，摂取頻 度が低い傾向にあると推察される。

次に, 魚介類についてみると,「3 日に 1 回」は 37.8 $\%$ ，「 2 日に 1 回」は33.1\%であった. 肉類は「 2 日に 1 回」が $45.1 \%$ と最も多く, 嗜好度の平均得点も 4.09 と 高かった. 主菜になる肉と魚では, 肉の方が好まれ摂取 頻度も高い傾向にあった．大豆・大豆製品は，「2 日に 1 回」 $26.7 \%$,「 3 日に 1 回」 $29.5 \%, 「 1$ 週間に 1 回」
$25.1 \%$ であり，「毎日食べる」は13.1\%と低かった。

また, 摂取頻度の高い食品は野菜類, 卵類, 乳・乳製 品であった. 乳・乳製品は, 「毎日食べる」が $49.2 \%$ と 約半数であり，嗜好度も高かった．卵類は「毎日食べる」 が $48.2 \%$ と約半数であり，次いで「 2 日に 1 回」が 28.3 \%であった．野菜類は「毎日食べる」が59.8\%と約 6 割 であり, 次いで「2 日に 1 回」が23.5\%であった。

次に, 食生活の簡便度をみるため, インスタント食品 やコンビニ弁当, ファーストフードの摂取状況をみた. カップラーメンなどのインスタント食品は, 「1 週間に 1 回」が43.2\%，「ほとんど食べない」が $34.4 \%$ 「゙っ 
表 2 女子学生における各種食品摂取頻度と嗜好度

\begin{tabular}{|c|c|c|c|c|c|c|c|c|c|c|c|c|}
\hline \multicolumn{7}{|c|}{ 摂取頻度 } & \multicolumn{6}{|c|}{ 嗜好度 } \\
\hline & 毎日食べる & 2 日に 1 回 & 3日に 1 回 & 1週間に1回1 & 食べない & 平均得点 ${ }^{(1)}$ & 好き & やや好き & ふつう & やや嫌い & 嫌い & 平均得点 $(2)$ \\
\hline 味噌汁 & 14.7 & 21.1 & 25.1 & 32.7 & 6.2 & 3.05 & 54.2 & 16.7 & 24.3 & 2.8 & 2 & 4.18 \\
\hline すまし汁・スープ & 2.4 & 4.8 & 13.5 & 53.8 & 25.2 & 2.05 & 39.8 & 25.9 & 29.9 & 3.6 & 0.8 & 4.00 \\
\hline 麺類 & 2.0 & 8.1 & 28.2 & 54.8 & 6.9 & 2.44 & 57.0 & 20.7 & 19.1 & 3.2 & 0 & 4.31 \\
\hline 漬け物 & 8.4 & 14.3 & 23.1 & 26.7 & 27.5 & 2.49 & 33.9 & 20.3 & 29.5 & 9.2 & 7.2 & 3.65 \\
\hline 塩干物 & 0.4 & 3.6 & 16.0 & 48.8 & 31.2 & 1.93 & 19.1 & 20.7 & 41.4 & 12.4 & 6.4 & 3.34 \\
\hline 佃煮・梅干しなど & 9.6 & 12.0 & 15.3 & 32.1 & 30.9 & 2.37 & 19.5 & 22.3 & 41.8 & 11.2 & 5.2 & 3.40 \\
\hline 卵類 & 48.2 & 28.3 & 14.3 & 7.6 & 1.6 & 4.14 & 49.4 & 24.7 & 20.3 & 3.6 & 2.0 & 4.16 \\
\hline 魚介類 & 12.7 & 33.1 & 37.8 & 11.2 & 5.2 & 3.37 & 41.0 & 21.1 & 26.3 & 10.0 & 1.6 & 3.90 \\
\hline 肉類 & 16.7 & 45.1 & 27.9 & 8.0 & 2.4 & 3.66 & 49.4 & 22.3 & 19.9 & 4.8 & 3.6 & 4.09 \\
\hline 野菜類 & 59.8 & 23.5 & 13.5 & 3.2 & 0 & 4.40 & 48.6 & 23.1 & 22.3 & 4.4 & 1.6 & 4.13 \\
\hline 大豆·大豆製品 & 13.1 & 26.7 & 29.5 & 25.1 & 5.6 & 3.17 & 28.8 & 20.8 & 32.8 & 14.4 & 3.2 & 3.58 \\
\hline 乳·乳製品 & 49.2 & 17.2 & 17.2 & 11.6 & 4.8 & 3.94 & 47.4 & 23.9 & 19.1 & 6.0 & 3.6 & 4.06 \\
\hline インスタント食品 & 0 & 6.0 & 16.4 & 43.2 & 34.4 & 1.94 & 20.3 & 24.3 & 35.1 & 13.9 & 6.4 & 3.38 \\
\hline コンビニ弁当 & 2.8 & 11.2 & 17.7 & 29.7 & 38.6 & 2.10 & 13.5 & 16.7 & 41.0 & 13.5 & 15.1 & 3.00 \\
\hline ファーストフード & 0.8 & 2.8 & 14.8 & 54.4 & 27.2 & 1.96 & 33.1 & 35.1 & 23.9 & 5.6 & 2.4 & 3.91 \\
\hline スナック菓子 & 10.4 & 23.1 & 23.9 & 25.9 & 16.7 & 2.84 & 43.0 & 21.9 & 24.3 & 7.2 & 3.6 & 3.94 \\
\hline $\begin{array}{ll}\text { 人数\% } & (1) \\
& (2)\end{array}$ & 日食べる & $\begin{array}{l}5 \text { 点 } 2 \\
\text { やや好き }\end{array}$ & 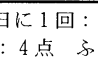 & 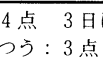 & $19 \sqrt{10}$ & 3 点 1 週 & 间に 1 回 & 2 点 食 & & 点とした & & \\
\hline
\end{tabular}

表 3 女子学生における各種食品摂取頻度の相関

\begin{tabular}{|c|c|c|c|c|c|c|c|c|c|c|c|c|}
\hline & 味噌汁 & $\begin{array}{l}\text { すむし汁。 } \\
\text { スープ }\end{array}$ & 麺類 & 漬け物 & 塩干物 & $\begin{array}{l}\text { 佃者·梅干 } \\
\text { しなど }\end{array}$ & 卵類 & 魚介類 & 肉類 & 野菜類 & $\begin{array}{l}\text { 大豆. } \\
\text { 大豆製品 }\end{array}$ & $\begin{array}{l}\text { 乳· } \\
\text { 乳製品 }\end{array}$ \\
\hline 味増汁 & 1.00 & & & & & & & & & & & \\
\hline すまし汁・スープ & $0.362 * *$ & 1.00 & & & & & & & & & & \\
\hline 麺類 & n.s. & $0.141 *$ & 1.00 & & & & & & & & & \\
\hline 漬け物 & $0.298 * *$ & $0.227 * *$ & n.s. & 1.00 & & & & & & & & \\
\hline 塩干物 & n.s. & $0.261 * *$ & n.s. & $0.403 * *$ & 1.00 & & & & & & & \\
\hline 佃煮・梅干しなど & $0.144^{*}$ & $0.148^{*}$ & n.s. & $0.384 * *$ & $0.253 * *$ & 1.00 & & & & & & \\
\hline 卵類 ～～～～～～～～ & $0.177 * *$ & $0.162 *$ & n.s. & $0.138 * *$ & $\mathrm{n} \cdot \mathrm{s}$ & $0.169 * *$ & 1.00 & & & & & \\
\hline 魚介類 & $0.211 * *$ & $0.157 *$ & n.s. & $0.187 * *$ & $0.264 * *$ & $0.142 *$ & $0.310 * *$ & 1.00 & & & & \\
\hline 肉類 & $0.171 * *$ & n.s. & $\mathrm{n} . \mathrm{s}$. & n.s. & $\mathrm{n} \cdot \mathrm{s}$ & n.s. & $0.383 * *$ & $0.388 * *$ & 1.00 & & & \\
\hline 野菜類 ～～～～～ & $0.275^{* *}$ & n.s. & n.s. & $0.212 * *$ & n.s. & $0.134 *$ & $0.232 * *$ & $0.358 * *$ & $0.241 * *$ & 1.00 & & \\
\hline 大豆·大豆製品 & $0.212 * *$ & $0.163^{* *}$ & n.s. & $0.170 * *$ & n.s. & $0.153 *$ & $0.355^{* *}$ & $0.412 * *$ & $0.225^{* *}$ & $0.331 * *$ & 1.00 & \\
\hline 乳·乳製品 & n.s. & $0.170 * *$ & n.s. & $0.140 *$ & $\mathrm{n} . \mathrm{s}$. & $0.131 *$ & $0.182 * *$ & $0.145^{*}$ & n.s. & $0.254 * *$ & $0.358 * *$ & 1.00 \\
\hline
\end{tabular}

た.コンビニ弁当は「ほとんど食べない」 $38.6 \%, 「 1$ 週間に 1 回」 $29.7 \%$ であった.しかし，「2 日に 1 回」 $11.2 \%$ ，「 3 日に 1 回」 $17.7 \%$ とよく利用している人も $2 \sim 3$ 割いた. コンビニ弁当の嗜好度平均得点は 3.0 点 で，特に好まれてはいないが，簡単で便利なため利用さ れていると考えられる. ファーストフードは, 嗜好度の 平均点が 3.91 と高く, 好んで利用されており，また「1 週間に 1 回」程度食べている人が, $54.4 \%$ と過半数であ った。

次に, 表 3 に女子学生における各種食品摂取頻度の順 位相関係数を示す. 味噌汁, 漬肳, 卵類, 野菜, 大豆. 大豆製品, 魚介類などは相関を示す食品が多く, 多種類
の食品を摂取する食事内容であることが推察された. 逆 に，麺類は有意な相関を示す食品がなく，食品の種類の 少ない食事内容であることが推察された。

味噌汁と有意な相関がみられたのは，相関係数の高い ものから順に, すまし汁・スープ, 漬け物, 野菜, 大豆· 大豆製品, 魚介類, 卵類, 肉類, 佃煮・梅干しなどであ った、味噌汁をよく飲む人は，和風の食事で多様な食品 を摄取しており，栄養のバランスも良いと考えられる。 一方，漬け物と塩干物は，佃煮・梅干しとも高い相関係 数を示し, 漬け物や塩干物をよく食べる人は佃煮・梅干 しもよく食べ，高塩分摂取に結びついていると考㝋られ る. 
表 4 女子学生における簡便食品と各種食品の㩒取頻度の相関

\begin{tabular}{|c|c|c|c|c|c|c|c|c|c|c|c|c|c|c|c|c|}
\hline & $\begin{array}{l}\text { インスタ } \\
\text { ソト食品 }\end{array}$ & $\begin{array}{l}\text { コンビニ } \\
\text { 弁当 }\end{array}$ & $\begin{array}{l}\text { ファースト } \\
\text { フード }\end{array}$ & 麺類 & $\begin{array}{l}\text { スナッ } \\
\text { ク菓子 }\end{array}$ & 味㽪计 & $\begin{array}{l}\text { すまし汁 } \\
\text { ・スープ }\end{array}$ & 漬物 & 塩干物 & $\begin{array}{l}\text { 佃者·梅干 } \\
\text { しなど }\end{array}$ & 卵類 & 魚介類 & 肉類 & 野菜類 & $\begin{array}{l}\text { 大豆·大 } \\
\text { 豆製品 }\end{array}$ & $\begin{array}{l}\text { 乳: } \\
\text { 乳製品 }\end{array}$ \\
\hline $\begin{array}{l}\text { インスタ } \\
\text { ソト食品 }\end{array}$ & 1.00 & & & & & n.s. & n.s. & n.s. & n.s. & $-0.163 * *$ & n.s. & n.s. & n.s. & $-0.134^{*}$ & n.s. & n.s. \\
\hline $\begin{array}{l}\text { コンビニ } \\
\text { 弁当 }\end{array}$ & $0.317 * *$ & 1.00 & & & & n.s. & n.s. & n.s. & n.s. & n.s. & n.s. & n.s. & n.s. & n.s. & n.s. & n.s. \\
\hline $\begin{array}{l}\text { ファース } \\
\text { トフード }\end{array}$ & $0.318^{* *}$ & $0.325^{* *}$ & 1.00 & & & n.s. & n.s. & n.s. & $0.154 *$ & n.s. & $-0.132^{*}$ & n.s. & n.s. & $-0.193 * *$ & $-0.127^{*}$ & n.s. \\
\hline 麺類 & $0.428 * *$ & $0.184 * *$ & $0.233 * *$ & 1.00 & & n.s. & $0.141^{*}$ & n.s. & n.s. & n.s. & n.s. & n.s. & n.s. & n.s. & n.s. & n.s. \\
\hline $\begin{array}{l}\text { スナック } \\
\text { 菓子 }\end{array}$ & $0.261 *$ & n.s. & $1.56^{*}$ & $0.187 * *$ & 1.00 & n.s. & n.s. & n.s. & $0.164 * *$ & n.s. & n.s. & n.s. & n.s. & n.s. & n.s. & $0.158 *$ \\
\hline
\end{tabular}

表 5 味増汁塩味嗜好テストと各種食品摂取頻度

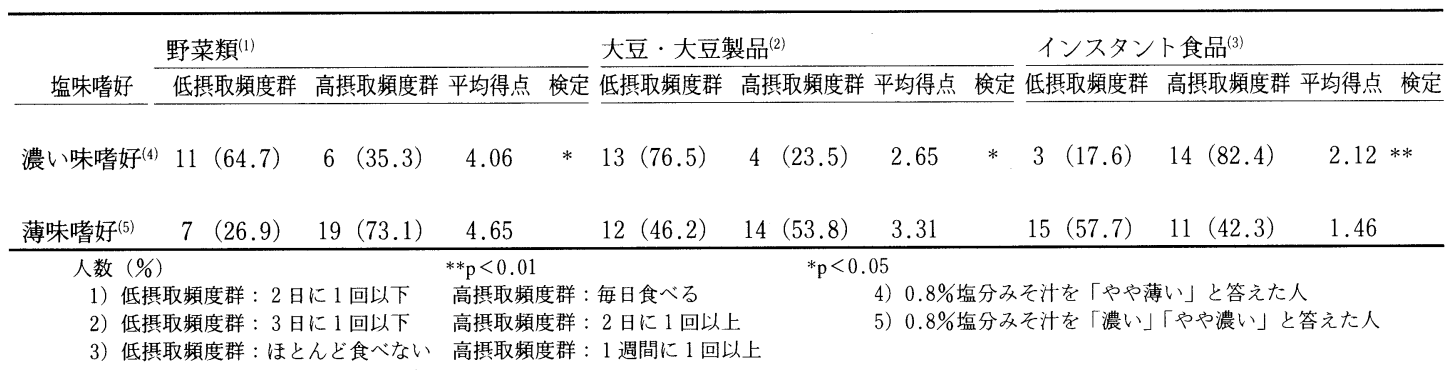

次に，食事の簡便性志向の状態をみるため, インスタ ント食品やコンビニ弁当, ファーストフード, 麺類など の摂取状況と各種食品の摂取状況の関係をみた．表 4 に 示す通り, インスタント食品, ファーストフード, コン ビニ弁当，麺類の摂取頻度は相互に有意な正の相関関係 がみられた。一方, インスタント食品は野菜類, 佃煮· 梅干しと, ファーストフードは野菜類, 卵類, 大豆·大 豆製品と負の関係が認められた．この結果から，これら の簡便な食品のいずれかの摂取頻度が高い人は，他の簡 便食品の摄取頻度も高いと考台れ，野菜や大豆·大至 製品といった健康的な食生活の指標となる食品をあまり 摂っていないことが分かった。

\section{4. 学生の食品摂取状況と官能検查結果の関係}

学生の食品摂取状況々塩味認知閾值の関係は有意な傾 向がみられなかった。学生の食品摂取状況と塩味莻好性 の関係をみるため, 味噌汁官能検査結果から抽出した

「濃い味嗜好」群と「薄味嗜好」群の両群について, 各 種食品摂取頻度を比較した。 その結果両群に有意な差が あった食品を表 5 に示す。野菜類は「2 日に 1 回以下」 を低摂取頻度群, 「毎日食べる」を高摂取頻度群とした。 「薄味赀好」の人は「毎日食べる」人が多く,「濃い味 箸好」の人は摂取頻度が低かった．大豆・大豆製品につ いてみると,「濃い味嗜好」の人は「3 日に 1 回以下」
の低摂取頻度の人が多かった。一方, インスタント食品 は逆の関係にあった。すなわち,「濃い味嗜好」の人は インスタント食品を「 1 週間に 1 回以上」摂取する高摂 取頻度群が多かった.

このような結果は, 比較的薄味を好む人は, 簡便な食 事よりも野菜類や大豆・大豆製品などを多く摂取し, 比 較的品数の多い食事を摂取している可能性を示唆している.

\section{4. 考察}

本研究では, 女子学生について味覚の感度や嗜好性に 対する食生活状況の影響を検討した。.その結果, 学生の 塩味に対する認知閾值や嗜好性に, 家庭の味付や本人お よび母親の減塩意識が関連する可能性が示唆された。す なわち, 家庭が薄味傾向の場合には, 学生の塩味認知閾 值が低く，また薄い味を好む傾向にあった。をた減塩意 識が高い学生では, 官能検査でも比較的薄い塩味を好む 傾向にあった。減塩意識については, 学生と母親の間に 相関がみられたが, 減塩意識の高い学生の割合は母親と 比べて著しく低く, 減塩に対する教育の必要性が示唆さ れた．また母親の減塩意識が高い場合には家庭の味が薄 い傾向にあることが推察された.

これらの結果は, 調査時における学生の食生活状況に 
ついて検討したものである. 子ども期における食生活環 境の影響についての研究では, 食品に対する喏好は幼児 とその両親では異なっていた2), 女子学生の味覚感度と 子ども期の食事状況とはほとんど関連性がなかっだ)， などの報告がみられる.

一方, 塩味への味覚形成に対する食塩摂取状況の影響 について多数の報告があるが, 生育時における食塩摂取 状況がどのように食塩の味覚形成へ影響するかについて は, いまだ明らかでない4 11)。今後, 生育時期の各段 階における食生活環境の味覚特性への影響を検討するこ とが望まれる.

本研究では, 味噌汁官能検査で濃い食塩濃度を好む学 生はインスタント食品の摂取頻度が高かった。インスタ ント食品の拄取頻度はコンビニ弁当, ファーストフード, 麺類，スナック菓子などの簡便な食品の摂取頻度と正の 相関関係にあり, 逆に, 簡便食品は野菜類, 大豆·大豆 製品, 卵類などと負の相関関係にあった。これらの結果 から, 食塩に対する嗜好性が高い学生は簡便食品の利用 が多く, 逆に野菜や大豆・大豆製品などの摂取が少ない 傾向が認められ, これらの学生に食塩掑取量が多い可能 性が示唆された。

近年, 調理済食品や弁当の消費が増大しているが，そ の問題点の一つに濃い味付があげられる. 高村らは市販 の弁当類や䊍菜類の食塩を測定して, その含量が高いこ とを報告した ${ }^{16)}$ 。学生の食生活状況に関する本研究結 果から, スーパーやコンビニなどの弁当, インスタント 食品, ファーストフード, スナック菓子などのうち, い ずれかの摄取頻度が高い場合には他の摂取頻度も高く, 食塩の過㮃拱取の危険性が推察された。一方, そのよう な場合には, 卵類, 野菜類, 大豆・大豆製品その他の食 品の摂取頻度は低く, 健康上問題があると考えられた。 このような学生の食生活状況をさらに検討するために, 母親へのアンケート結果の解析を現在進めている.

\section{まとめ}

女子学生の塩味に対する感度や嗜好性などの味覚特性 を官能検査により調べ，また本人と家庭における調理担 当者の食生活に対する意識や実態をアンケート調査によ り調べて, 塩味に対する感度や嗜好性への食生活状況の 影響を検討した。

その結果, 家庭が薄味傾向の場合には, 学生の塩味認 知閾值が低く、また薄い塩味を好む傾向にあった。 また 減塩意識が高い学生では, 比較的薄い塩味を好む傾向に あった. 減塩意識については, 学生と母親の間に相関が
みられ，また母親の減塩意識が高い場合には家庭の味が 薄い傾向にあると推察された.これらの結果より, 女子 学生の塩味に対する認知閾值や嗜好性に, 家庭の味付や 本人および母親の減塩意識が関連する可能性が示唆され た.

また, インスタント食品, スーパーやコンビニなどの 弁当, ファーストフードなどのうち, いずれかの摂取頻 度が高い場合には他の摂取頻度も高く, 一方, 野菜類, 大豆・大豆製品, 卵類などの摂取頻度が低いことが認め られた。をた，そのような場合には濃い塩味を好む傾向 にあった. 女子学生の食生活状況の中に, 食塩の過剩摂 取や栄養素摂取のアンバランスなど健康上の問題がある ことが推察された.

\section{文献}

1) 厚生省保健医療局 地域保健 - 健康増進栄養課生活習慣病 対策室監修: 国民栄養の現状 (平成 9 年国民栄養調査結果), 第一出版, p.39 (1999)

2）田口田鶴子, 岡本洋子 : 幼児の食味嗜好性および味覚閾值, 家政誌, 44, 115 (1993)

3) 岡本洋子, 田口田鶴子: 子ども期の食事がその後の味覚感 受性や性格特性に及ぼす影響, 家政誌, 48, 621（1997）

4) Bertino, M., Beauchamp, G.K., and Engelman, K.: Increasing dietary salt alters salt taste preference, Physiol. Behav. 38, 203 (1986)

5) Teow, B.H., DiNicolantonio, R., and Morgan, T.O.: Sodium chloride preference and recognition threshold in normotensive subjects on high and low salt deit, Clin. Exp. Hypertens [A], 7, 1681 (1985-1986)

6) Shepherd, R., Farleigh, C.A., and Land, D.G.: The relationship between salt intake and preferences for different salt levels in soup, Appetite, 5, 281 (1984)

7) Blais, C.A., Pangborn, R.M., Borhani, N.O., Ferrell, M.F., Prineas, R. J., and Laing, B.: Effect of dietary sodium restriction on taste responses to sodium chloride: a longitudinal study, Am. J. Clin. Nutr., 44, 232 (1986)

8) Bertino, M., Beauchamp, G.K., and Engelman, K.: Longterm reduction in dietary sodium alters the taste of salt, Am. J. Clin. Nutr., 36, 1134 (1982)

9) Ayya, N., and Beauchamp, G.K.: Short-term effects of diet on salt taste preference, Appetite, 18, 77 (1992)

10) DiNicolantonio, R., Teow, B.H., and Morgan, T.O.: Sodium detection threshold and preference for sodium chloride in humans on high and low sodium diets, Clin. Exp. Pharmacol. Physiol., 11, 335 (1984)

11) Drewnowski, A., Henderson, S.A., Driscoll, A., and Rolls, B.J.: Salt taste perceptions and preferences are unrelated to sodium consumption in healthy older adults, J. Am. Diet Assoc., 96, 471 (1996)

12）田口田鶴子, 岡本洋子 : 老年期の人々の甘・酸・塩に対す る喏好傾向と味覚閾値, 家政誌, 41, 509 (1990)

13）岡本洋子, 田口田鶴子：小学生の食味嗜好傾向および味覚 
閾値, 家政誌, 47, 161 (1996)

14）今中正美, 道本千衣子:女子学生の味覚の変化について, 家政誌, 50, 1091 (1999)

15）石田裕美 : 若年成人女子における潜在的亜鉛欠乏と塩味に
対する味覚, 日本栄養·食糧学会誌，46，229（1993）

16）高村仁知, 近藤聡子, 岡野悦子, 荻野麻理, 松澤一幸, 山 中信介, 的場輝佳 : 市販の弁当類および総菜類におけるミ ネラル含量とその問題点, 家政誌, 50，377 (1999) 